\title{
Universal Covenant affirming a human right to commons- and rights-based governance of Earth's natural wealth and resources ${ }^{*}$
}

\section{PReAmble}

The 1948 Universal Declaration of Human Rights assertion that "Everyone is entitled to a social and international order in which the rights and freedoms set forth in this Declaration can be fully realized"1 necessarily mandates a clean and healthy environment, without which human beings cannot fully enjoy their rights.

The principles set forth in the 1972 Stockholm Declaration of the United Nations Conference on the Human Environment ${ }^{2}$ unequivocally stipulate that "Man has the fundamental right to freedom, equality and adequate conditions of life, in an environment of a quality that permits a life of dignity and well-being,"3 and that "[the environment] must be safeguarded for the benefit of present and future generations through careful planning or management, as appropriate."4

The scientific validity of global climate change and its underlying human causes is authoritatively substantiated by the United Nations Intergovernmental Panel on Climate Change (IPCC) with ominous environmental predictions for the near- and long-term future (the loss of land, forests, freshwater systems, and biodiversity and the increasing frequency of severe weather patterns, including intensified storms, prolonged draught, hurricanes, monsoons, typhoons, and climate shifts) accompanied by hardships to humankind (famine, displacement, disease, and violence) and to other living beings.

* Prepared for the Commons Law Project by Burns H. Weston and David Bollier with assistance from Samuel M. Degree, Matthew J. Hulstein, and Dinah L. Shelton in the early stages and Jonathan C. Carlson, Anne Mackinnon, and Anna Grear in the final stage. Copyright (C) 2013 by Burns H. Weston and David Bollier. However, this Covenant (or "Green Governance Covenant"), as modestly revised in this Version 1.1, may be copied and shared under a Creative Commons AttributionNonCommercial-ShareAlike 3.0 license (https://creativecommons.org/licenses/by-sa/3.0/us). Indeed, it is encouraged that it be so shared and acted upon widely-adjusted to situational circumstance as needed, of course. To that end, the Covenant is available for downloading, printing, and dissemination on the Commons Law Project website (http://www.commonslawproject.org).

1. Universal Declaration of Human Rights (UDHR), art. 28, G.A. Res. 217A, at 71, U.N. GAOR, 3d Sess., 1st plen. mtg., U.N. Doc. A/810 (10 Dec 1948), reprinted in III INTERNATIONAL LAW And World Order: Basic Documents, at III.A.1 (Burns H. Weston \& Jonathan C. Carlson eds., 1994- ) (hereinafter "BASIC DocuMENTs" for all five titles), available at http://nijhoffonline.nl/ subject?id=ILWO (accessed July 3, 2012).

2. Stockholm Declaration of the United Nations Conference on the Human Environment (16 June 1972), U.N. Doc A/CONF.48/14/Rev.1 at 3, available at http://www.unep.org/ Documents.Multilingual/Default.asp?documentid=97\&articleid=1503; reprinted in V BASIC DocUMENTS, supra note 1, at V.B.3.

3. $\quad I d$., Principle 1.

4. $\quad I d$., Principle 2. 
Other worsening environmental crises with stressful and life-imperiling consequences for humans and other beings include the depletion of non-renewable resources, the improper disposal of hazardous wastes, the defilement of precious food and water supplies, and the overall contamination and degradation of delicate ecosystems.

State and Market abuse and destruction of nature has accelerated since the advent of an essentially unregulated globalization of capital. Investor and corporate interests, often with the active partnership of governments, unrelentingly exploit and pollute energy resources and increasingly commercialize water and other natural wealth and resources once considered beyond the reach of technology and markets.

The lack of international consensus for the principles embodied in the 1997 Kyoto Protocol $^{5}$ to the 1992 United Nations Framework Convention on Climate Change ${ }^{6}$ and the 1992 Convention on Biological Diversity, ${ }^{7}$ as well as the failure of these and other environmental instruments to protect the natural environment sufficiently to safeguard life on Earth for present and future generations, is well known.

The continuing failure of the world's leaders to acknowledge or address the most fundamental causes of the accelerating ecological and social devastation of our planet, as manifested at the COP 15/MOP 52009 United Nations Climate Change Conference in Copenhagen and the 2012 Rio+20 United Nations Conference on Sustainable Development in Rio de Janeiro, is unacceptable.

State and Market leadership has either forgotten or neglects the fact that the authority of the State and the power of private business enterprise stem from the people as sovereign, and from the institutions of civil society that they have created to serve collective human interests.

Also forgotten or neglected, often not even understood, is the reality that the interests of humanity are interdependent with the interests of other creatures that cohabit our planet, and that therefore humanity cannot be adequately protected and sustained without recognizing and defending the rights of nature and of all beings within its surround.

It thus appears that a new system of ecological governance capable of recognizing nature's worth and of embracing greater civil society participation must be developed if nature is to be adequately protected and nourished.

The world community has recognized Antarctica, the deep seabed, and outer space as within "the interest of all mankind" or part of the "common heritage of mankind" in the 1959 Antarctic Treaty ${ }^{8}$ the 1982 United Nations Convention on the Law of the Sea, ${ }^{9}$ and the 1967 Treaty on Principles Governing the Activities of States in the Exploration and Use of Outer Space, Including the Moon and Other Celestial Bodies. ${ }^{10}$

However, the deep seabed's "common heritage" status was subsequently denied by powerful State and Market forces whose self-interests were threatened by it; the Outer

5. FCCC/CP/1997/7/Add.1, reprinted in 37 I.L.M. 32 (1998) and BASIC DocumENTS, supra note 1 , at V.H.8a.

6. 1771 U.N.T.S. 107, reprinted in 31 I.L.M. 849 (1992) and BASIC DocumENTS, supra note 1, at V.H.8.

7. 1760 U.N.T.S. 79, reprinted in 31 I.L.M. 818 (1992) and BASIC Documents, supra note 1, at V.N.14.

8. 402 U.N.T.S. 71, reprinted in 19 I.L.M. 860 (1980) and BASIC DocumENTS, supra note 1, at V.D.1.

9. 1833 U.N.T.S. 3, reprinted in 21 I.L.M. 1261 (1982) and BASIC DocUMENTS, supra note 1, at V.I.22.

10. 610 U.N.T.S. 205, reprinted in 6 I.L.M. 386 (1967) and BASIC DocUmENTS, supra note 1, at V.P.1. 
Space Treaty has yet to be put to the real test of competing economic, political, and strategic priorities; and the Antarctic regime is increasingly threatened by the same kinds of forces and priorities.

On the other hand, the global proliferation of the Internet and new digital technologies is today enabling imaginative new forms of informal, self-organized, collaborative governance on open platforms that provide powerful means for aggregating and distributing ecological information, coordinating collective responses, enlisting the knowledge and innovation of commoners, and improving management systems, all of which are enabling important "eco-digital" commons that can help preserve our planet and other vital ecological interests.

For millennia, human communities have successfully and sustainably managed the use of ecological resources through commons-based governance, and these practices have long been sanctioned by national and international law, as has also the right of individuals and groups to establish and maintain commons to protect their vital ecosystems (the right of commoning).

The historical record and social science research demonstrate the ability of communities of varying sizes and kinds to manage natural wealth and resources equitably, allocate access and use-rights fairly, and preserve resources essentially unimpaired for present and future generations, thus serving as responsible long-term stewards of ecological resources.

International law and policy increasingly validate these truths as, for example, in the 1992 People's Earth Declaration ${ }^{11}$ — adopted by the International NGO forum of 170,000 civil society participants at the Global Forum that met parallel to the 1992 United Nations Conference on Environment and Development (UNCED) — which proclaims that "[o]rganizing economic life around decentralized relatively self-reliant local economies that control and manage their own productive resources and have the right to safeguard their own environmental and social standards is essential to sustainability."

Especially notable is the 1998 Convention on Access to Information, Public Participation in Decision-Making and Access to Justice in Environmental Matters, ${ }^{12}$ which codifies the central importance of public participation in setting environmental policy and calls on its State Parties to take every reasonable step to foster such participation.

Also validating is the 2005 Paris Declaration on Biodiversity, ${ }^{13}$ in which scientists participating in the International Conference on Biodiversity Science and Governance-organized by the French Government, sponsored by UNESCO, and attended by over 1,000 participants representing governments, inter-governmental organizations and non-governmental organizations, as well as academia and the private sector-urged governments, policy makers, and citizens to take the actions necessary to ensure that "biodiversity [be] integrated without delay, based on existing

11. Adopted June 12, 1992, reprinted in V BASIC DocumENTs, supra note 1, at V.K.2; also available at http://habitat.igc.org/treaties/at-01.htm (accessed July 3, 2012).

12. UNECE Convention on Access to Information, Public Participation in Decision-Making and Access to Justice in Environmental Matters, 25 June 1998, 2161 U.N.T.S. 447, U.N.Doc. ECE/CEP/43, reprinted in 38 I.L.M. 517 (1999) and V BASIC DocUMENTS, supra note 1, at V.B.20; also available at http://live.unece.org/fileadmin/DAM/env/pp/documents/cep43e.pdf (accessed July 3, 2012).

13. Adopted Jan. 28, 2005. reprinted in 8 J. InT'L WiLdLIFE LAW AND Policy 263 (2005) and V BAsic Documents, supra note 1, at V.K.4; also available at htttp://www.unesco.org/new/ fileadmin/MULTIMEDIA/HQ/SC/pdf/Paris_declaration_biodiversity.pdf (accessed July 5, 2012). 
knowledge, into the criteria considered in all economic and policy decisions as well as environmental management."

Noteworthy, too, is a growing recognition of the severity of humankind's abuse of its planetary environment, the unprecedented threat it poses to future generations, and the disastrous harm it has begun already to unleash upon nature and society worldwide.

Hence the emergence of a proposed crime of "ecocide," first in a 1972 Proposed International Convention on the Crime of Ecocide born of the use of Agent Orange during the Vietnam war; ${ }^{14}$ more recently urged as a fifth international crime of peace under the 1998 Rome Statute of the International Criminal Court; ${ }^{15}$ and today, in the context of the evolving disasters resulting from the excessive emission of greenhouse gases into the atmosphere and the scant State or Market resolve to stop it, seriously contemplated as a crime against humanity. ${ }^{16}$

Hence also the 2000 Earth Charter $^{17}$ — created by a global consultation process and endorsed by organizations representing millions of people around the world-which calls for "a sustainable global society founded on respect for nature, universal human rights, economic justice, and a culture of peace" and to these ends affirms it to be "imperative that we, the peoples of Earth, declare our responsibility to one another, to the greater community of life, and to future generations."

And hence, too, the 1997 UNESCO Declaration on the Responsibilities of the Present Generation Towards Future Generations ${ }^{18}$ and the 2010 Draft Universal Declaration of the Rights of Mother Earth, ${ }^{19}$ the purposes of which are self-evident from their titles.

Energizing, then, is the World Social Forum's 2009 Reclaim the Commons Manifesto ${ }^{20}$ calling upon "all citizens and organizations to commit themselves to recovering the Earth and humanity's shared inheritance and future creations" and in so doing "demonstrate how commons-based management-participatory, collaborative and transparent-offers the best hope for building a world that is sustainable, fair and life-giving."

14. Adopted by the Emergency Conference against Environmental Warfare in Indochina, at Stockholm, June 1972. Available at 4 Bull. Peace Proposals 93 (1973). Reprinted in V Basic Documents, supra note 1, at V.V.1 (accessed July 5, 2012).

15. Adopted by the United Nations Diplomatic Conference of Plenipotentiaries on the Establishment of an International Criminal Court, July 17, 1998, UN Doc. A/CONF.183/9 (July 17, 1998); reprinted in 37 I.L.M. 999 (1998) and I BASIC DocumenTs I.H.18, supra note 1.

16. See, e.g., Polly Higgins, Closing the Door to Dangerous Industrial Activity: A Concept Paper for Governments to Implement Emergency Measures http://www.eradicatingecocide. com/wp-content/uploads/2012/02/Ecocide-Concept-Paper.pdf (accessed July 11, 2012).

17. Adopted at The Hague by the Earth Charter Commission, June 29, 2000, available from the Earth Charter Commission at http://www.earthcharter.org, reprinted in V BASIC DocumENTS, supra note 1 , at V.K.3.

18. Adopted Nov. 12, 1997 on the report of UNESCO Commission V at the 27th plenary meeting of the UNESCO General Conference. Available at http://unesdoc.unesco.org/images/ 0011/001102/110220e. pdf\#page=75 (accessed July 5, 2012).

19. Adopted Apr. 22, 2010 by the World People's Conference on Climate Change and the Rights of Mother Earth at Cochabamba, Bolivia. Available at http://celdf.org/downloads/ FINAL \%20UNIVERSAL \% 20DECLARATION\%20OF\% 20THE\%20RIGHTS\%20OF\% 20MOTHER\%20EARTH\%20APRIL\%2022\%202010.pdf (accessed July 5, 2012).

20. Opened for signature at the World Social Forum in Belém do Pará (Brazil), January 2009. Available at bienscommuns.org. Reprinted in V BAsIC DocumenTs, supra note 1, at V.K.5 (accessed July 5, 2012). 
THEREFORE, keenly aware of the urgency of taking decisive, collective action to transform existing systems and structures of ecological governance so as to reduce climate change, loss of biodiversity, and other severe threats to Earth's life-giving and life-sustaining capacity,

WE,

CALL UPON all citizens, organizations, and governments of the world to commit themselves to recovering the Earth and humanity's shared inheritance and future creations, and in furtherance of this pledge

AFFIRM a Universal Human Right to Commons- and Rights-based Ecological Governance as a common standard of achievement for all humankind, and to this end

ADOPT, PROCLAIM, AND IMPLEMENT this Universal Covenant, mutatis mutandi, by all manner of constitutional, legislative, administrative, judicial, and private sector initiative to facilitate the prompt and sustained recognition and observance of its ascribed definitions, principles, rights, and duties at all levels of social organization at home and around the world.

\section{Article I. Commons- And Rights-Based Ecological Governance}

All natural persons have a human right to commons- and rights-based ecological governance (green governance).

1. Commons- and rights-based ecological governance is a system for using and protecting all the creations of nature and related societal institutions that we inherit jointly and freely, hold in trust for future generations, and manage democratically in keeping with human rights principles grounded in respect for nature as well as human beings, including the right of all people to participate in the governance of wealth and resources important to their basic needs and culture.

2. Typically, commons- and rights-based ecological governance consists of nonState management and control of natural wealth and resources by a defined community of natural persons (commoners), directly or by delegation, as a means of inclusively and equitably meeting basic human needs. It generally operates independently of State control and need not be State-sanctioned to be effective or functional.

3. Where appropriate or needed, the State may act as a guardian or trustee for commons- and rights-based ecological governance or formally facilitate its principles and practices by establishing commons-like State institutions to manage publicly owned natural wealth and resources.

\section{Article II. Principles of Internal Governance}

1. The natural environment is the common heritage of all humankind, belonging to all natural persons present and future, and shall be respected as such by all commons- and rights-based governance systems.

2. Commons- and rights-based governance systems shall at all times responsibly account for the fragile and complex interdependence of living ecosystems, social and cultural norms, the aesthetic value of the environment, the interests 
of future generations, and the ultimate dependence of humankind on our Earth for health and survival.

3. Social cooperation, trust, and reciprocity are essential to the success of commons- and rights-based ecological governance.

a. To these ends the self-determined constitutive and operational rules of green governance systems must be conducive to ensuring that

1) reliable information is available about the immediate and long-term costs and benefits of actions as measured in both quantitative and qualitative terms;

2) individual commoners understand that their shared resources are important for their own interests and long-term security, and therefore are motivated to act as trustworthy, reciprocal, and openly communicative commoners in the shared management of ecological resources;

3) informal as well as formal monitoring of resource use and sanctioning of rules-violators are feasible and considered appropriate; and

4) the culture, leadership, and historical continuity of a commons enable it to adapt and learn in addressing ecological management challenges over time.

b. To these ends also the self-determined constitutive and operational rules of green governance systems shall guarantee to all involved individuals and groups:

1) the right to be informed, which includes

a) the right to prior notice of proposed decisions and policies that may significantly affect their common assets, governance covenant, community ethos, and cultural identity;

b) the right to clear and complete information on the ecological impact of activities that may significantly affect their common assets, governance covenant, community ethos, and cultural identity;

c) the right to effective access to legislative, administrative, judicial, or other proceedings during which decisions that may have significant ecological impact upon the common assets are under discussion; and

2) the right to participation, which includes

a) when practical, the right to participate directly in decisions affecting their common assets, governance covenant, community ethos, and cultural identity;

b) in the absence of a practical opportunity for direct participation, the right to adequate representation of their interests in the stewardship of common assets;

c) the right to consistent and meaningful access to any representative ecological decision-makers as well as effective mechanisms of communication and accountability;

d) the right to timely and accessible public hearings before decisions are made that may significantly affect their common assets, governance covenant, community ethos, and cultural identity; and

3 ) the right to recourse, for themselves or as surrogates for future generations, from competent internal decision-making institutions or processes for redress of violations of their rights to ecological information and participation.

4. Human rights (applicable to both present and future generations) and nature's rights (applicable to all species present and future) are likewise essential to 
the success of commons- and rights-based ecological governance, including the human right to commons- and rights-based ecological governance recognized in this Universal Covenant.

a. To this end, commons- and rights-based ecological governance shall embody the values of human dignity as expressed in the 1948 Universal Declaration of Human Rights ${ }^{21}$ and such human rights treaties evolved from it that have been designated "core international human rights instruments" by the Office of the United Nations High Commissioner for Human Rights. ${ }^{22}$

b. To the same end, commons- and rights-based ecological governance shall embody the values expressed in the Universal Declaration of the Rights of Mother Earth adopted by the World People's Conference on Climate Change and the Rights of Mother Earth in 2008 and submitted by the Plurinational State of Bolivia to the United Nations for consideration in $2010 .^{23}$

c. If and when the application of human rights and nature's rights differ or conflict, such disagreement shall be resolved in a way that best promotes the integrity, balance, and health of Earth for the benefit of present and future generations and other beings.

5. Commons- and rights-based ecological governance shall be based on the principle of local control and subsidiarity to the maximum extent feasible. Green governance by default should aspire to the lowest level of policy- and decisionmaking possible, with conscientious and generous support from institutions of greater scale and authority.

6. To protect common assets, commons- and rights-based ecological governance systems shall conscientiously adhere to a precautionary approach when threats of damage to ecological resources are serious or potentially irreversible. Lack of full scientific certainty shall not be used as justification for postponing costeffective measures to prevent environmental degradation.

7. Commoners shall have collective control over the surplus value they create through the collective management of their shared wealth and resources. To this end, commons- and rights-based ecological governance shall not be cash-driven or market-mediated except with the explicit consent of commoners and clear rules for personal use and resource alienability. The freedom of commoners to limit or ban the monetization of their shared assets shall not be compromised.

8. Property rights granted by commons- and rights-based governance systems for use of natural wealth and resources to individuals or groups (public, private, or commons-based) are not absolute; they must conform to the principles and practices of commons- and rights-based ecological governance as recognized and reaffirmed in this Universal Covenant.

9. Conflicts and disputes within commons- and rights-based ecological governance systems shall be settled through self-organized dispute resolution systems to the maximum extent feasible, using techniques and procedures that favor dialogue, mutual respect, and restorative outcomes among the disagreeing parties.

21. Supra note 1.

22. See Office of the United Nations High Commissioner for Human Rights (OHCHR) at http://www2.ohchr.org/english/law/index.htm\#core (accessed July 5, 2012).

23. Supra note 17. 
Article III. Principles and Policies to Guide State Support of CommonsAND Rights-Based ECOlogical Governance

1. Earth belongs to everyone, and its services and infrastructure are necessary for the well-being and survival of all humans and other species. The State shall therefore facilitate and safeguard commons- and rights-based governance of Earth's wealth and resources as part of its mission to protect, conserve, and restore (where necessary) the integrity, health, and sustainability of the vital ecological balances, cycles, and processes that nourish communities and enhance all life on Earth. In these critical respects, the State shall strive to work as a generous partner, not a selfish overlord, of green governance systems.

2. In furtherance of foregoing Article III(1), the State and its agents at all levels shall:

a. recognize and promote the full implementation and enforcement of the principles, rights, and obligations proclaimed or reaffirmed in this Universal Covenant, including the human right to commons- and right-based ecological governance recognized herein;

b. without financial burden, assist commoners in fulfilling their rights to current, timely, and clear ecological information, including but not limited to:

1) the compilation, maintenance, and regular updating by all public authorities of environmental information relevant to their functions,

2) the assessment of the ecological impact of any activity that may significantly impact the environment, especially large-scale common-pool resources and prompt publication thereof on the Internet, with opportunities for public dialogue, and

3) the facilitation of crowdsourcing of knowledge, information, and new initiatives to assist State activities designed to support the Commons Sector.

c. further and similarly assist the public by guaranteeing its rights to participation in ecological decision- and policy-making and to justice in environmental matters, ensuring, inter alia, that individuals exercising their rights, including their rights to petition government, are not penalized, persecuted, or otherwise harassed or disadvantaged for raising and expressing their ecological concerns;

d. fully and actively support the right of all individuals and groups, sanctioned by national and international law and reaffirmed in this Universal Covenant, to protect, conserve, and restore (where necessary) their vital ecosystems via commons governance in national, subnational, and transnational settings;

e. in exercise of its partnership with commons- and rights-based ecological governance, collaborate with established and new green governance systems in the invention, recommendation, and initiation of new policy structures (normative, institutional, and procedural) that could work effectively to manage large-scale national, transboundary and global common-pool resources; and

f. cooperate fully with other States, appropriate intergovernmental organizations (including the United Nations and its system of organizations), and civil society in respect of vital ecological matters largely beyond the limits of the State's territorial jurisdiction, in particular in respect of large-scale transboundary and global common-pool resources, and the invention, recommendation, and initiation of effective new policy structures for the management of them. 
3. In keeping with foregoing Articles I(4) and III(1), when ecological or economic conditions require, the State may:

a. serve as a trustee of common-pool resources belonging to commoners if the commoners so authorize or if protection of a given resource so requires it; and

b. charter or otherwise authorize responsible parties to manage common-pool resources as ecological commons when such stewardship can be shown to serve the public interest;

c. provided, however, that in each of the foregoing instances the State, its agents, and its surrogates shall create transparent and accountable ecological management systems under State law that are compatible with commons- and rightsbased ecological governance principles, rights, and duties, and that beneficiary interests are well served with effective accountability systems. Commoners' rights shall not be alienated or diminished except for the purpose of protecting the commoners' shared resources for future generations.

4. The State has an affirmative duty to prevent enclosures of ecological commons and common-pool resources. To this end, it shall formally recognize such commons and resources by State law to the maximum possible.

5. The State has an affirmative duty also to ensure that private property ownersindividuals and commercial interests alike-shall exercise maximum caution not to externalize environmental risks, damage, or costs onto the environment in general or ecological commons in particular, or otherwise act in ways that are incompatible with the principles, rights, and duties of commons- and rights-based ecological governance. To this end, the State shall, among other environmentally protective policies, conscientiously adhere to:

a. a precautionary approach to prevent human activities from causing species extinction, the destruction of ecosystems, or the disruption of ecological cycles onto ecological commons in particular and the wider environment in generalthe lack of full scientific certainty never to be used as justification for postponing cost-effective measures to prevent environmental degradation, especially when such degradation is serious or potentially irreversible; and

b. the principle that the polluter, not the general public or the commoner, remedies any harm that may occur despite best efforts - the remedy, however, shall not be considered the equivalent of the ecological loss if it be in the form of financial compensation exclusively and therefore shall not be considered exhaustive of remedial responsibility, which shall include, but not be limited to, restoration of the integrity and health of the damaged resource to the maximum extent possible; ecosystems and their elements are not fungible.

6. The State has an affirmative duty to eliminate nuclear, chemical, and biological weapons, all of which are antithetical to a clean and healthy environment, including common-pool ecological resources (managed or unmanaged).

\section{Article IV. Duties of Market Actors towards Commons- and Rights-Based ECOLOGICAl Governance}

1. Market actors, comprised of both natural and juridical persons, shall honor and respect the existence and expansion of commons- and rights-based ecological governance and, to the extent possible, support the human right to commons- and 
rights-based ecological governance recognized in this Universal Covenant. To this end, they shall:

a. act in accordance with the principles, rights, and duties recognized in this Universal Covenant, including the full realization of the human right to commons- and right-based ecological governance recognized in this Universal Covenant;

b. recognize and promote the full implementation of the aforementioned principles, rights, and duties to the maximum of their capabilities;

c. cooperate fully with State officials in their efforts to facilitate commons- and rights-based ecological governance systems, in particular by providing, when requested, clear, current, transparent and timely environmental information to State and Commons officials alike; facilitating active commoner participation in ecological governance; and helping to ensure commoner access to justice in environmental matters, when needed.

2. Market actors shall conscientiously establish and apply effective norms to protect, conserve, and restore (where necessary) the natural resources with which they become involved, including the shared resources of ecological commons. In this regard, they shall assess fully and transparently any proposed activity of their own that might impact adversely the environment in general and common-pool ecological resources in particular. If ecological harm results nonetheless, the market actor, not the general public or commoners, shall remedy the harm. The remedy, however, shall not be considered the equivalent of the ecological loss if it be in the form of financial compensation exclusively, and therefore shall not be considered exhaustive of the market actor's responsibility, which shall include, but not be limited to, restoration of the integrity and health of the damaged resource to the maximum extent possible; ecosystems and their elements are not fungible.

3. Market actors shall cooperate fully with ecological commons systems, State officials, intergovernmental organizations, and civil society in the management of vital ecological resources, both within and beyond the limits of their domiciles (in the case of natural persons) or executive and operational headquarters (in the case of juridical persons), in particular in respect of large-scale transboundary and global common-pool resources. Market actors shall be invited to help invent, recommend, and initiate effective new policy structures for Market activity that are consistent with commons- and rights-based ecological management.

4. At no time shall private actors seek to undermine or otherwise compromise commons- and rights-based ecological governance systems. They shall undertake, instead, to partner with green governance systems, not to compete with or undermine them, in the preservation, conservation, and, where necessary, restoration of vital ecological resources, including vital common-pool ecological resources.

5. Market actors shall at all times cooperate with the State in fulfillment of its affirmative duty to eliminate nuclear, chemical, and biological weapons, as well as other toxic substances antithetical to a clean and healthy environment, including common-pool resources whether managed or unmanaged.

\section{Article V. (Duties of United Nations and Other Intergovernmental Organizations)}

1. The United Nations and its system of organizations shall contribute to the extent of their capacities to the creation, support, and proliferation of commons- and 
rights-based ecological governance through the mobilization of financial cooperation, technical assistance, and other methods and means of promoting such governance.

a. To this end, the Member States of the United Nations and the intergovernmental organizations that have agreed to achieve eight Millennium Development Goals (MDGs) ${ }^{24}$ by 2015 , including "ensuring environmental sustainability," shall strive both before and, if possible, after 2015, to make the creation, support, and proliferation of commons- and rights-based ecological governance an integral part of the MDG policy frame.

b. The United Nations and its system of organizations shall contribute also to the full realization of the human right to commons- and rights-based ecological governance recognized and defined in this Universal Covenant. In this regard,

1) the General Assembly shall formally recognize this right to green governance, and, in accordance with Article 22 of the Charter of the United Nations, shall establish and actively support a subsidiary organ empowered to refer cases to the International Court of Justice for compulsory advisory opinions on all matters pertinent to said right; and

2) the United Nations shall use its good offices to establish a permanent Ecological Governance Oversight Panel (or equivalent) charged with responsibility to help safeguard the human right to commons- and rights-based ecological governance for present and future generations. The Panel shall have legal standing before the Human Rights Council and all other relevant United Nations bodies, both treaty and non-treaty, on all matters pertinent to this right.

2. All other appropriate intergovernmental organizations-including but not limited to such global institutions as the International Monetary Fund (IMF), the World Bank, and the World Trade Organization (WTO); and such regional systems as the African Union (AU), the Association of Southeast Asian Nations (ASEAN), the European Union (EU), and the Organization of American States (OAS) - shall

a. at all times cooperate with the United Nations and its system of organizations in their efforts to promote and protect both commons- and rights-based ecological governance and the full realization of the universal right of all natural persons to it as set forth in this Universal Covenant; and

b. to the extent of their financial, technical, and other capacities take initiatives of their own to promote and protect both green governance and the full realization of the universal right of all natural persons to it as set forth in this Universal Covenant.

24. Millennium Development Goals, http://www.un.org/millenniumgoals (accessed July 8, 2012). 